\title{
Gynaecological Problems among Elderly Women Living in Old Age Homes of Kathmandu Valley
}

\author{
Marina Vaidya Shrestha ${ }^{1 *}$, Sunil Kumar Joshi ${ }^{1}$ and Sampathia Gopalakrishnan ${ }^{1}$ \\ ${ }^{\prime}$ Department of Community Medicine, Kathmandu Medical College, \\ Sinamangal, Kathmandu, Nepal
}

\section{CORRESPONDENCE:}

Marina Vaidya Shrestha

Department of Community Medicine, Kathmandu Medical College, Sinamangal, Kathmandu, Nepal

Email: merinavs@gmail.com

ISSN : 2382-5359(Online), 1994-1412(Print)

DOI:

https://doi.org/10.3126/njst.v20i1.39439

\section{ACCESS THE ARTICLE ONLINE}

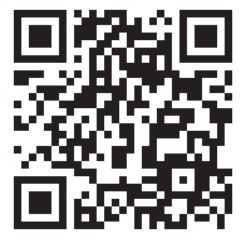

\section{CONFILICT OF INTEREST: None}

Copyright: The Author(s) 2020. This is an open access article under the CC BY license.

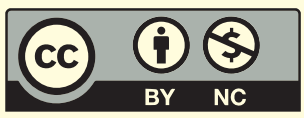

\begin{abstract}
Ageing is a natural process. The elderly population is increasing in Nepal.When there is presence of diseases, physical inability, and financial harshness, the elderly in Nepal have to face many problems. This study was thus conducted to assess the socio-economic milieu and spectrum of gynaecological problems among women living in old age homes of Kathmandu valley. For this a cross sectional study was conducted in 19 old age homes of three districts of Kathmandu valley. In this study, they were 234 particants. Privacy and confidentiality of information about the individual were strictly maintained. One-third of the aged women living in the old age homes belonged to 70-80 years. $50.9 \%$ were from outside Kathmandu valley, while $49.1 \%$ were from the valley. The elderly were mostly not visited by their relatives and friends. Most of them (74.4\%) were interested in praying than other activities. Out of the total Urine samples (190), 68.4\% were normal, and $9.4 \%$ had a urinary tract infection. There were only $15.6 \%$ uterine prolapse cases. Out of total, $70.9 \%$ of Pap smear report was normal, while $25.1 \%$ had inflammatory smear. This study revealed that the old age homes have become a shelter for most of elderly women. The socio-economic condition was poor. Gynaecological probems like UTI, Urinary incontinence were not high but the prolapse cases (uterine proplase, cystocele, rectocele) were remarkably high. Cervical cancer screening through Pap smear showed negative results.
\end{abstract}

Keywords: Ageing, prolapse, geriatric population, pap smear, urinary incontinence.

\section{INTRODUCTION}

Ageing is a natural process and should be regarded as a normal, inevitable biological phenomenon(Park2013).According to World Population Prospects, in 2019, one in $11(9 \%)$ and by 2050, one-sixth of people (16\%) will be over 65 years (UN 2020). Currently, an estimated 728 million persons aged 65 years or over in the world and the global population aged 65 years or over are expected to increase from 9.3 percent in 2020 to around 16.0 percent in 2050 (UN 2020).

In Nepal, life expectancy has increased from 63.9 years in 2000 to 71.7 years in 2020 (worldometer 2020). The elderly in Nepal have to face many physical, socio-economical, psychological problems, and many others (Chalise et al. 2020). Very little research is carried out focusing on issues of elderly people in Nepal (Chalise 2005). This study has therefore assessed 
the socio-economic milieu and spectrum of gynaecological problems among older women living in old age homes of Kathmandu valley.

\section{MATERIALS AND METHODS}

\subsection{Study Design}

This cross-sectional study was conducted in 19 old age homes of three districts of Kathmandu valley. Among which thirteen were from Kathmandu, five from Lalitpur, and one from Bhaktapur. The study population comprised only women above 60 years of age. It was conducted from May 2012 to September 2012.

The participants were communicated in Nepali or Newari. The mentally disabled, those not available at the time of data collection, severely ill, unwilling to participate, and the unmarried older women (as vaginal examination is not done for this group)were excluded from the study. The sample size of the survey was determined using the following formula:

Population sample size $(\mathrm{n})=\mathrm{Z}^{2} \mathrm{pq} / \mathrm{d}^{2}$

where, $\mathrm{z}=$ level of confidence according to the standard normal distribution (for a level of confidence of $95 \%, z=$ 1.96)

$\mathrm{p}=$ prevalence of gynaecological problems $=28 \%=0.28$ (Takkar et al., 2010),

$\mathrm{d}=$ tolerated margin of error $=5 \%$

Hence, the sample size $(\mathrm{n})$ calculated $=309.76$. Considering $10 \%$ non-respondent, the sample size design for this research $=n+10 \%$ of $n=340.736 \approx 341$.

There were 354 women living in the old age homes we visited, out of which only 234 were the participants; 120 were unwilling to participate in this study. In each old age home, the study participants were included by a convenient sampling technique.

\subsection{Data Collection Tools and Technique}

For data collection, the tools used were pretested questionnaires and the instruments for a Gynaecological check-up. A semi-structured questionnaire was used, which comprised of different socio-demographic variables. Which was conducted in each of the old age homes. The interview lasted for 15-30 minutes for each woman and also sometimes more than 30 minutes. The interview was taken maintaining privacy. Only the interviewer and the participant were present at the time of the interview.

The instruments like Cusco's vaginal speculum, gloves and wooden spatula for a Pap smear used during the examination, were fully sterilized and used single time for each patient. After the vaginal examination, the instruments were disinfected and gloves packed in plastic, was handed over to old age homes staff for safe burial. During gynaecological check-up, Pap smear was done with a wooden spatula. The number was marked in each patient's slide and was dipped in ethyl alcohol for five minutes and was taken out and collected in a slide box. The collected slides were taken to the pathology lab, where those were examined. To collect the urine samples, sterilized urine bottles were collected from the lab and coded with numbers to identify the participant's sample. The collected urine was stored in a vaccine storage box with an icebox placed in every four corners. The samples were taken to the lab on the next day in the early morning hours.

\subsection{Ethical Consideration}

Ethical approval from the Institutional review committee of Kathmandu Medical College was taken. The objectives of the study were explained clearly to the authorized person of old age homes and the participants. Written informed consent was taken from those participants who can read and write, and for those who were unable to read and write, permission from old age home authority was taken. Information was taken only for study purposes only. No information was taken and published, which can break the anonymity of the respondents. Privacy and confidentiality of information about the individual were strictly maintained. In all aspects, the autonomy of the study participants was fully respected and ensured.

The data were analyzed using the Statistical Package for the Social Sciences software (SPSS) 20. Descriptive analysis was done. Frequency, mean, percentage, interquartile range was calculated.

\section{RESULTS}

\subsection{Socio-demographic Profile}

The total number of elderly participants in this study was 234. The median age of the elderly who participated was 75 years, and the interquartile range was 12.25 . The majority in between $70-80$ years were 78 (33.3\%), and in the age group of $60-70$ were $71(30.3 \%)$. Out of total elderly participants, $50.9 \%$ belonged to outside Kathmandu valley, while $49.1 \%$ were from the valley. The majority of the participants $(\mathrm{n}=181,77.4 \%)$ believed in Hinduism while (n=50) $21.4 \%$ in Christianity. Out of total participants, 28.6 $\%$ were Brahmin while $24.4 \%$ were Newar and $21.8 \%$ 
were Chettri, 14.1\% were from combined janjatis. Among the participants living in old age homes $79 \%$ were illiterate while only $7.7 \%$ were literate. From the past occupational history $51.3 \%$ were engaged in agriculture, and $32.5 \%$ were housewives. In this study, $53.4 \%$ of participants were widows, $20.9 \%$ were married, $13.7 \%$ were separated, $9.8 \%$ were unmarried, and $2.1 \%$ were divorced. Most of the older women living in old age homes belonged to nuclear families $(n=203,87 \%)$, and only $(n=31) 13 \%$ had joint families (Table1).

Table 1. Demographic profile of Elderly participants $(n=234)$.

\begin{tabular}{|c|c|}
\hline Variables & Frequency n(\%) \\
\hline \multicolumn{2}{|l|}{ Age } \\
\hline $60-70$ & $71(30.3)$ \\
\hline $71-80$ & $78(33.3)$ \\
\hline $81-90$ & $75(32.0)$ \\
\hline $90+$ & $10(4.4)$ \\
\hline \multicolumn{2}{|l|}{ Address } \\
\hline Inside valley & $115(49.1)$ \\
\hline Outside valley & $119(50.9)$ \\
\hline \multicolumn{2}{|l|}{ Religion } \\
\hline Hindu & $181(77.4)$ \\
\hline Christian & $50(21.4)$ \\
\hline Buddhist & $3(1.2)$ \\
\hline \multicolumn{2}{|l|}{ Ethnicity } \\
\hline Brahmin & $67(28.6)$ \\
\hline Chettri & $51(21.8)$ \\
\hline Janajati & $83(35.6)$ \\
\hline Others & $33(14.0)$ \\
\hline \multicolumn{2}{|l|}{ Education } \\
\hline Not literate & $185(79.0)$ \\
\hline Literate & $18(7.7)$ \\
\hline Primary & $28(11.9)$ \\
\hline Above Primary & $3(1.4)$ \\
\hline
\end{tabular}

\begin{tabular}{|l|l|}
\hline Marital status & $49(21.0)$ \\
Unmarried & $23(9.8)$ \\
Widow & $125(53.4)$ \\
Divorced & $5(2.1)$ \\
Separated & $32(13.7)$ \\
\hline Past Occupation & $120(51.3)$ \\
Agriculture & $76(32.5)$ \\
Housewife & $9(3.8)$ \\
Private service & $8(3.4)$ \\
Business & $21(9.0)$ \\
Others & $203(87)$ \\
\hline Types of family & $31(13)$ \\
Nuclear & \\
Joint & \\
\hline
\end{tabular}

\subsection{Socio Economic Profile}

The longest period of years spent in old age homes was 15 to 30 years by $(n=14) 5.9 \%$. The highest number of participants who lived for one to five years in those old age homes was $48.2 \%$. $47.4 \%$ of the elderly participants did not have anyone to visit them while staying in old age homes, while $33.3 \%$ had monthly visitors. Regarding the source of economic support, $44 \%$ did not have any source, while $56 \%$ had some source of income from old age allowance, widow allowance, bank balance, home rent. A maximum number of older women living in old age homes spent their leisure time doing vajan-kirtan (45.7\%) while $43 \%$ watched television. Elderly women living in old age homes were more interested in praying than any other activities (74.4\%) while $19.2 \%$ were involved in meditation.

Regarding the living environment of old age homes where they lived, $85 \%$ were satisfied with the quality of food given while $13.7 \%$ complained of being dominated and the same percentage had felt the problems of theft of their goods. When the older women were asked about their perception of old age and its impact on their lives, 53\% expressed old age had affected their day-to-day life, and $20.5 \%$ felt that their family members neglected them.53.8\% of the older women living in old age homes felt satisfied with their lives, while $46.2 \%$ were unhappy (Table2). 
Table 2. Socio-economic profile of the elderly women $(n=234)$.

\begin{tabular}{|c|c|}
\hline Socio-economic profile & $\begin{array}{l}\text { Frequency n } \\
(\%)\end{array}$ \\
\hline \multicolumn{2}{|l|}{ Source of economic support } \\
\hline No & $103(44)$ \\
\hline Yes & $131(56)$ \\
\hline From government (allowances) & $100(76.34)$ \\
\hline Siblings & $4(3.05)$ \\
\hline Self-earned & $16(12.21)$ \\
\hline Children & $2(1.53)$ \\
\hline Others & $9(6.87)$ \\
\hline \multicolumn{2}{|c|}{ Leisure time spent in old age homes* } \\
\hline Watching TV & $101(43)$ \\
\hline Talking with friends & $59(25)$ \\
\hline Bhajan-kirtan & $107(45.7)$ \\
\hline Reading holy books & $1(0.43)$ \\
\hline Making batter for pooja & $29(12.4)$ \\
\hline Listening to music or vajan & $35(15)$ \\
\hline \multicolumn{2}{|l|}{ General activities* } \\
\hline Prayers & $174(74.4)$ \\
\hline Meditation & $45(19.2)$ \\
\hline Yoga & $31(13.2)$ \\
\hline Exercise & $14(6)$ \\
\hline \multicolumn{2}{|c|}{ The living environment of old age home* } \\
\hline Satisfy with the quality of food & $199(85.0)$ \\
\hline The feeling of being dominated & $32(13.7)$ \\
\hline Problem of theft & $32(13.7)$ \\
\hline \multicolumn{2}{|l|}{ Satisfaction in Life } \\
\hline Yes & $126(53.8)$ \\
\hline No & $108(46.2)$ \\
\hline
\end{tabular}

We could not find elderly / disabled friendly infrastructure in these old age homes we visited according to our check list. Most of the old age homes were a 2-3 storey constructed building. The elderlies had difficulty to do up and down. Next was the distance of the toilet and hand washing facility. Except in 2 of the old age homes (with attached bathrooms), we observed that the distance between the living room of the elderlies and the toilet facility was noticeable. For this reason, the elderly used to skip night meals and drinking water. The number of hand washing facilities and toilet facilities was not according to the number of the old aged peple. Similarly, in most of the old age homes, the regular visiting doctors or staff nurses were lacking, but few of the old age homes had hired nursing staff for daily duty and visiting doctors weekly or monthly where the old aged peple could get health care and benefit.

\subsection{Gynaecological Problems}

In this study, the complain of urinary incontinence among the elderly population, were reported by $23 \%$ only. There were 21 uterine prolapsed cases among 134 cases seen. Of which $33.3 \%$ were categorized in grade I, $52.3 \%$ as grade II, $14.4 \%$ as grade III. Similarly, 27.6\% had cystocele and rectocele. (Table.3)

Table 3. Cases of uterine prolapse.

\begin{tabular}{|l|l|}
\hline Cases seen among(n=134) elderly & Frequency $\mathbf{n}(\mathbf{\%})$ \\
\hline Uterine prolapse & $\mathbf{2 1 ( 1 5 . 6 )}$ \\
\hline Grade I & $7(33.3)$ \\
\hline Grade II & $11(52.3)$ \\
\hline Grade III & $3(14.4)$ \\
\hline Cystocele & $\mathbf{3 7 ( 2 7 . 6 )}$ \\
\hline Grade I & $33(89.1)$ \\
\hline Grade II & $4(10.9)$ \\
\hline Grade III & 0 \\
\hline Rectocele & $\mathbf{3 7 ( 2 7 . 6 )}$ \\
\hline Grade I & $34(91.8)$ \\
\hline Grade II & $3(8.2)$ \\
\hline Grade III & 0 \\
\hline
\end{tabular}

The urine routine report showed that $68.4 \%$ were normal, $9.4 \%$ of the sample had urine infection (i.e. pus cells were plenty).Out of 131 Pap smear reports, $70.9 \%$ were normal and $25.1 \%$ were inflammatory (Table 4 ).

Table 4. Reports of pap smear test $(n=131)$

\begin{tabular}{|l|c|c|c|c|c|c|c|}
\hline & A & B & C & D & E & F & G \\
\hline Frequency(n) & 93 & 33 & 1 & 1 & 1 & 1 & 1 \\
\hline Percent (\%) & 70.9 & 25.1 & 0.7 & 0.7 & 0.7 & 0.7 & 0.7 \\
\hline
\end{tabular}

Note: $\mathrm{A}=$ Normal smear report, $\mathrm{B}=$ Inflammatory, $\mathrm{C}=$ Inflammatory with bacterial vaginosis

$\mathrm{D}=$ Inflammatory with reactive atypia, $\mathrm{E}=$ Atrophic without inflammation, $\mathrm{F}=$ Low grade squamous intraepithelial lesions, $\mathrm{G}=$ Atrophic with inflammation 


\section{DISCUSSION}

Old age people are a vulnerable group and therefore need more attention and care. Globally population growth of older people is expected to continue growing more rapidly than any other group. The present study conducted at different old-age homes reveals various details regarding health and socio-economic aspects among the elderly.

In this study majority (33.3\%) of the older women were between the age group of 70-80 years, and the median age of the respondents was 75 years. A similar result was found in a study done in old age homes in Kaski District and Kathmandu (Lamichhane 2017, Khanal 2018). A little different trend was seen in the study done in different cities in India (Zalavadiya 2018, Mishra 2016, Brahmbhatt 2019, Rao 2015, Patel 2015) where the mean age was slightly different as 72 years and the majority of women age was in between 60-70 years, but the common trend in all these studies was females outnumbered the males. Regarding educational status, most elderlies were illiterate $(79 \%)$ in this study. A similar result was seen in the old age homes of Kaski (Lamichhane 2017), where all-female elderlies were illiterate, and the study of old age homes in Kathmandu and India also showed higher illiteracy (Khanal 2018 \&Patel 2015). In the study done in South Gujrat, 36.7\% were illiterate (Mishra 2016). Compare to ours, the study in old age homes in Gujarat showed the least illiteracy (23.87\%) among females (Brahmbhatt 2019). The question raised here that whether illiteracy could be one of the major causes for the old aged people to settle down in old age homes because they could not speak for their rights. The highest number of participants who lived in those old age homes was $48.2 \%$ for $1-5$ years. Similar findings were found in a study done in old age homes in Kathmandu and India (Khanal 2018, Mishra 2016, Rao 2015 and Patel 2015), but in a study done in old age homes in Gujrat, majorities were living there for 6-10 years (Brahmbhatt 2019). Most of the older women who were living in old age homes belonged to nuclear families. The contrast was seen in a study done at old age homes in Ahmedabad (Rao 2015), where most of them were from joint families.

Regarding the source of economic support, $56 \%$ did not have any source. Only $44 \%$ had some source of income from old age allowance, widow allowance, bank balance, home rent. The study of old age homes in Kaski and Kathmandu also showed that many old aged people do not have any source of income (Lamichhane 2017 \& Khanal 2018). The same case was seen in a study done in India (Rao 2015). A maximum number of older women living in old age homes spent their leisure time doing vajan- kirtan and watching television. Similarly, in old age homes of Kaski, old aged people enjoy vajan kirtan and Yoga (Lamichhane 2017). Regarding the living environment of old age homes where they lived, most were satisfied with the quality of food given. This regularity was in contrast to the case of old age homes in Kaski (Lamichhane 2017). Only few elderlies were satisfied with the food provided in old age homes .

This study was focused on older women and their health problems. So regardless of other common geriatric problems, the study focused on gynaecological problems, which were quite similar to a hospital-based study in India (Takkar et al. 2010); most of the other studies reviewed showed the general geriatric health problems (Mishra 2016; Chalise 2020; Mishra 2018; Banker 2011).

Due to the lack of a proper database of the old age homes in the Kathmandu Valley, it was not easy to involve all old age homes to achieve the required sample size. This study could have been complete if more diagnostic technical tools like ultra sonography and urine culture were also done.

\section{CONCLUSION}

This study explored that the old age homes have become a shelter for most of elderly women and more than half of them were satisfied with their life. The socio-economic conditions was poor. Physical infrastructures and health facilities of existing old age homes were insufficient. Gynaecological probems like UTI, Urinary incontinence were not high but the prolapse cases (uterine proplase, cystocele, rectocele) were remarkably high. Cervical cancer screening through Pap smear showed negative results.

Physical infrastructures and facilities and regular health services in each old age home should be in accordance with standard guidelines, which need to be prepared by the government. Healthy activities like yoga and other recreational programs should be encouraged.

\section{ACKNOWLEDGMENT}

With a sense of deep gratitude, I would like to thank Professor Dr. Gopala Krishnan Sampathia, my preceptor and late Professor Dr. Indur Dudani for their advice, encouragement for my thesis work. I would also like to express my sincere thanks to Dr. Chandrika Shrestha for her support in the preparation of the Pap smear report. I highly appreciate all the old-age homes of Kathmandu Valley for their priceless support. 


\section{REFERENCES}

1. Banker, K., B. Prajapati. and G. Kedia. 2011. Study of the health profile of residents of the geriatric home in Ahmedabad district. National Journal of Community Medicine Vol 2 Issue 3. http://www.njcmindia.org/ uploads/2-3_378-382.pdf

2. Brahmbhatt, N. and T.A.Shah. 2019. A cross-sectional study of health and psychosocial problems among elderly people living in old-age homes of Ahmedabad and Gandhinagar districts, Gujarat, India International Journal of Medical Science and Public Health. Vol 8:Issue 11.doi:10.5455/ijmsph.2019.0823330082019

3. Chalise,H.N. and S.Shrestha.2005. The situation of the elderly in the Himalayan Kingdom of Nepal. Indian Journal of Social Work, 66(2):136-143. http://ijsw.tiss.edu/ greenstone/collect/ijsw/index/assoc/HASHafb7/db270b14. dir/doc.pdf

4. Chalise, H.N. B.R. Paudel.and S. Mishra. 2020. Dental and Eye Problem of Nepali Older Adults Living in Old Age Home. J Health Care and Research. Mar 24;1(1):16-19. https://doi.org/10.36502/2020/hcr.6155

5. Khanal, P., S. Rai. and H.N. Chalise. 2018. Children's Migration and Its Effect on Elderly People: A Study at Old Age Homes in Kathmandu. Am J Gerentol Geriatr.; 1(1): 1001http://www.remedypublications. com/open-access/pchildrenrsquos-migration-and-itseffect-on-elderly-people-a-study-at-old-age-homes-inkathmandup-2031.pdf

6. Lamichanne, S. 2017. Senior citizens and old age homes: a study of pushing factors and level of satisfaction in old age homes of Kaski district. Thesis. Department of Sociology. http://107.170.122.150:8080/xmlui/ bitstream/handle/123456789/938/All\%20thesis. pdf? sequence $=1 \&$ isAllowed $=y$

7. Mishra, A.K. and N.Mishra. 2016. Physical Status of Elderly People in Old Age Homes in South Gujarat: An Overview. International Journal of Health Sciences \& Research. Vol.6; Issue: 2; https://www.ijhsr.org/ IJHSR_Vol.6_Issue.2_Feb2016/38.pdf

8. Mishra, S. and H.N.Chalise. 2018. Health Status of Elderly living in Government and Private Old Age Home in Nepal. Asian J.Biol.Sci.11(4):173-178 DOI: 10.3923/ajbs.2018.173.178

9. Park, k. 2013. Park'Park's textbook of preventive and social medicine, 22nd edition, Jabalpur, Banarsidas Bhanot publishers.:547-549.

10. Patel, P.G., U.P.Patel. and N.Thakor. 2015. Profile of elderly inmates of old age homes of Patan district, Gujarat, India: a cross-sectional study. Int $\mathrm{J}$ Res Med Sci. Oct;3(10):2725-2728DOI: http://dx.doi. org/10.18203/2320-6012.ijrms20150821

11. Rao, A.N. Y.Trivedi and V.Yadav. 2015. Assessing the Life Satisfaction of Elderly Living in Old Age Homes in the City of Ahmedabad. Indian Journal of gerontology. Vol. 29, No. 2, pp. 154-169 https://www. ijhsr.org/IJHSR_Vol.6_Issue.2_Feb2016/38.pdf

12. Takkar, N, P. Goel, D. Dua, H. Mohan and A.Huria. 2019. The spectrum of gynaecological disorders in older Indian women, a hospital-based study, Asian journal of gerontology and geriatrics 2010; Vol.5, No2,69-73. http://ajgg.org/image/module/ajgg _ issue/14/AJGGOA2010-69.pdf

13. United Nation. World population prospects. Department of economic and social affairs population dynamics. https://population.un.org/wpp/

14. United Nations. 2020. Government policies to address population aging. Population facts. Department of Economic and social affairs. October 2020 | No. 2020/1.https://www.un.org/development/desa/ $\mathrm{pd} /$ sites/www.un.org.development.desa.pd/files/ files/documents/2020/Oct/undesa_pd_2020_pf_ government_policies_population_ageing.pdf

15. Worldmeter. 2020. Nepaldemographics https://www. worldometers.info/demographics/nepal-demographics/

16. Zalavadiya, D.D., A. Banerjee., N.B. Joshi., C.N. Bhola. and A.M.Sheth. 2018. A Comparative Study of Morbidity Profile of Elderly Residing in Old Age Homes and the Community of a Tier-II City in India. Natl J Community Med;9(7):480-485. http://njcmindia. org/uploads/9-7_480-485.pdf 